\title{
A Study on Mergers and Acquisition in India and Its Impact on Operating Efficiency of Indian Acquiring Company
}

\author{
Natika Poddar \\ St. Francis Institute of Management and Research, Mumbai, India \\ Email: natika@sfimar.org
}

How to cite this paper: Poddar, N. (2019) A Study on Mergers and Acquisition in India and Its Impact on Operating Efficiency of Indian Acquiring Company. Theoretical Economics Letters, 9, 1040-1052. https://doi.org/10.4236/tel.2019.94067

Received: January 28, 2019

Accepted: April 21, 2019

Published: April 24, 2019

Copyright $\odot 2019$ by author(s) and Scientific Research Publishing Inc. This work is licensed under the Creative Commons Attribution International License (CC BY 4.0).

http://creativecommons.org/licenses/by/4.0/

\section{cc) (i) Open Access}

\begin{abstract}
Merger and Acquisition had been the most popular means of inorganic expansion of companies over the years. It is extensively used for restructuring the business organizations. Companies undertake mergers and acquisitions based on strategic business motivations that are, in principal, economic in nature. This research study attempts to evaluate the impact of pre and post financial performance of the acquirer companies. This will be done by comparing the pre-merger and post-merger performance of the acquirer company in selected M \& A deals in India in two periods-2007-2008 (selected due to 2008 global financial crisis) and 2012-2013 (Many deals rose after 2010 and then again in 2012-2013) using select financial ratios and paired t test at 5\% significance.
\end{abstract}

\section{Keywords}

Mergers, Acquisition, Pre, Post, Operating, Performance

\section{Objective of the Study}

- To analyze the impact of M \& A on the acquirer's operating efficiency.

- To understand Macroeconomic environment besides the effects of the Merger, which impacts the performance of the Acquirer.

\section{Review of Literature}

The paper from Amish Bharat Kumar Soni [1] highlights about financial analysis impact of the Acquired company. Paper also highlights shareholders wealth analysis as a short term investment.

Harpreet Singh Bedi [2] "Merger \& Acquisition in India: An Analytical Study": The paper explores the trends and progress in M \& As in India. It also considers 
various factors that have facilitated in Progress and execution of M \& As in India.

The paper from Viral Upendrabhai Pandya [3] tries to measures the mergers and acquisitions sector of India from 1991 to 2010 with the help of time-series data along with major recent worldwide development. This paper also tries to categorize trends in manufacturing and non-manufacturing sectors to provide definite evidence for motives and reasons behind the particular behavior observed, and the prospective future of mergers and acquisitions activity in India.

Rabi Narayan Kar and Amit Soni's paper [4] emphasized on stating mergers as a strategy to enhance the Enterprise value. Researchers analyzed and selected the period post liberalization to analysis the impact of the Mergers.

Agnihotri [5] investigate and analyzed determinants of acquisitions in three industries in India and find that the volatility of earnings and business group affiliation has a significant influence on acquisitions by Indian firms. The paper focused more on increase in earnings due to Acquisitions.

Erel, Liao, \& Weisbach [6] reveals in the paper that acquisitions take place when perceived advantage in the form of production efficiencies, market power, and tax considerations are higher for combined entities compared to Pre-Acquisition. Researcher suggests in the paper that a firm should perceive sufficient benefits from a cross border acquisition before it prefers to pursue an international acquisition strategy.

Kumar [7] discusses about the transformation of Hindalco, an Indian aluminium producer into one of the world's largest aluminum manufacturers, suggests that while firms from the developed world use M \& A for cost saving and size synergies; emerging market firms are motivated by a strategy to acquire competencies, brands, knowhow and technology that could transform them into global leaders. As the emerging market $M$ \& A are not driven by the desire for cost saving, downsizing, etc integration is smoother and less disruptive.

\section{Research Methodology}

The Company selected for the study would be for the period for which the Merger and Acquisition happened in the period 2007-2008 and 2012-13. The acquiring company selected for study are Indian companies. Secondary data for 3 years period for pre-merger and post-merger would be taken for analysis. Ratios giving information on operating efficiency considered for study.

\section{Hypothesis}

H0: There is no significant difference in the mean efficiency ratio of the selected Acquirer company pre-merger and post-merger.

H1: There is significant difference in the mean efficiency ratio of the selected Acquirer company pre-merger and post-merger.

To verify hypothesis T-test will be conducted to understand the effect of mergers on the operating efficiency of the company before and after merger. The test will be considered at $5 \%$ significance. 


\section{Introduction}

Mergers and Acquisitions (M \& A) are defined as consolidation of companies. Difference between the two terms, Mergers is the combination of two companies to form one, wherein Acquisitions is one company taken over by the other. M \& $\mathrm{A}$ is one of the important aspects of corporate finance world. The idea behind $\mathrm{M}$ \& $\mathrm{A}$ is generally given is that the two separate companies together create more value compared to being on an individual stand. With the main objective of wealth maximization, companies keeps on evaluating different opportunities through the route of merger or acquisition. In this, always synergy value is created by the joining or merger of two companies. The synergy value can be analysed either through the Revenues (higher revenues), Expenses (lowering of expenses) or the cost of capital (lowering of overall cost of capital).

Its obvious that, both sides of an M \& A deal will have different ideas about the worth of a target company: Its seller wants to value the company at as high of a price as possible, while the buyer would try to get the lowest price that he can.

There are, however, many legitimate ways to value companies. The most common valuation method is to look at comparable companies in an industry, but deal makers implements a variety of other methods and tools when assessing a target company. Some of them are as follows:

Comparative Ratios. The following are two examples of the many comparative metrics on which acquiring companies may base their offers:

Price-Earnings Ratio (P/E Ratio) - With this ratio, An acquiring company makes an offer that is a multiple of the earnings of the target company. Looking at the $\mathrm{P} / \mathrm{E}$ for all the stocks within the same industry group will give the acquiring company good guidance for what the target's P/E multiple should be [4].

Enterprise-Value-to-Sales Ratio (EV/Sales) - With this ratio, the acquiring company makes an offer as a multiple of the revenues, again, while being aware of the price-to-sales ratio of other companies in the industry [4].

Replacement Cost-In a very few cases, acquisitions are based on the cost of replacing the target company. For simplicity's sake, suppose the value of a company is simply the sum of all its equipment and staffing costs. The acquiring company can literally order the target to sell at that price, or it will create a competitor for the same cost. Naturally, it takes a long time to assemble good management, acquire property and get the right equipment [8].

Discounted Cash Flow (DCF)-This is a key valuation tool in M \& A. Discounted cash flow analysis determines a company's current value according to its estimated future cash flows. Forecasted free cash flows (net income + depreciation/amortization - capital expenditures - change in working capital) are discounted to a present value using the company's weighted average costs of capital (WACC) [8].

\section{The Premium for Potential Success}

Acquiring companies nearly always pay a substantial premium on the stock 
market value of the companies they buy for. The justification for doing so nearly always boils down to the notion of synergy; a merger benefits shareholders when a company's post-merger share price increases by the value of potential synergy [9].

It would be highly unlikely for rational owners to sell if they would benefit more by not selling. That means buyers would have to pay a premium if they hope to acquire the company, regardless of what pre-merger valuation tells them. For sellers, that premium represents their company's future prospects. For buyers, the premium represents part of the post-merger synergy they expect can be achieved.

Companies undertake mergers and acquisition based on strategic business motivations that are, in principal, economic in nature. These include leverage on economies of scale which covers any, some or all areas of research and development, production and marketing (Horizontal mergers); widen distribution capabilities or newer markets aimed at augmenting market share; diversify range of products and services (Diversification of Business); getting advantage of professional leadership by being acquired (by a smaller company); survive headwinds systematic and macro environment by combing ranks [9].

Other factors can also be included such as achieving pricing efficiency in the supply chain by acquiring a channel partner (vertical merger) or even exclude future competition. The mergers acquisition activity has also led to the internationalization of business operations. Mergers \& Acquisition have been increasingly resorted to as a fast and effective strategy of consolidation, especially in the cross-border landscape. These are mainly driven by the fluid global economic environment with companies from the emerging economies rushing to acquire cross-border assets at competitive prices especially post the 2008 Global Financial Crisis. Many Indians companies are looking out for international companies, especially in the west to increase market share and or augment efficiencies. This shift is especially visible in the Information Technology, Metals, Pharmaceuticals and Life Sciences and Automobile and ancillaries sectors.

The primary driver amongst Merger and Acquisition is to maximize shareholder value i.e. by increase in the market value of the firm due to the merger. This can be achieved by increasing its profits, which, in turn, can be achieved by cost efficiency of scale, economies of scope and economies of vertical integration and synergies through cost savings-research and development, rationalization, purchasing power, creating internal capital markets and financial savings-tax and interest rates [4].

In recent times, mergers and acquisition have been a panacea for highly leveraged companies. This trend is seen especially after 2015, as the banking sector became strict in lending. Unlike in the past, where growth was the major driver of most $\mathrm{M} \& \mathrm{~A}$ deals, over leverages companies attempted to reduce debt by selling assets.

\section{Data and Methodology}

The corporate deals selected for analysis are Mergers and Acquisitions that are 
cross-border in nature, and the acquiring company is an Indian company and has happened in the period 2007-08 and 2012-13.Period selected 2007-2008 which was during the period of global recession and 2012-13 was the period wherein major deals took place. Hence the two years were selected for the study.

The following M \& A deals have been selected for analysis.

2007-08

\begin{tabular}{l}
\hline DrReddys Laboratories-Betapharm \\
Colgate-Palmolive \\
Tata Motors-Jauguar \\
Suzlon-RE Power \\
ONGC-Imperial \\
Hindalco-Novelis \\
Tata Steel-Corus \\
HDFC-Centurion BOP \\
Reliance Industries-IPCL \\
Indian oil Corp-IBP \\
JSW-SISCOL
\end{tabular}

1) Dr. Reddy's Laboratories is an Indian multinational pharmaceutical company based in Hyderabad, Telangana, India. The company was founded by Anji Reddy, who previously worked in the mentor institute Indian Drugs and Pharmaceuticals Limited, of Hyderabad, India [3].

2) Colgate-Palmolive Company is an American worldwide consumer products company focused on the production, distribution and provision of household, health care and personal care products [3].

3) Tata Motors Limited is an Indian multinational automotive manufacturing company headquartered in Mumbai. It is a subsidiary of Tata Group, an Indian conglomerate. Its products include passenger cars, trucks, vans, coaches, buses, sports cars, construction equipment and military vehicles [5].

4) Suzlon Energy Ltd. is a wind turbine supplier based in Pune, India. It was formerly ranked by MAKE as the world's fifth largest wind turbine supplier. It has since dropped out of the Global top ten rankings due to extensive losses and inability to repay debts [5].

5) Oil and Natural Gas Corporation (ONGC) is an Indian multinational oil and gas company earlier headquartered in Dehradun, Uttarakhand, India. It is a Public Sector Undertaking (PSU) of the Government of India, under the administrative control of the Ministry of Petroleum and Natural Gas.

6) Hindalco Industries Ltd., an aluminium and copper manufacturing company, is a subsidiary of the Aditya Birla Group. Its headquarters are at Mumbai, Maharashtra, India. It is the Flagship company of the company in the metals business. The company has annual sales of US\$ 15 billion and employs around 20,000 people [7]. 
7) HDFC Bank Limited is an Indian banking and financial services company headquartered in Mumbai, Maharashtra. It has 88,253 permanent employees as of 31 March 2018 and has a presence in Bahrain, Hong Kong and Dubai. HDFC Bank is India's largest private sector lender by assets [7].

8) Reliance Industries Limited is an Indian conglomerate holding company headquartered in Mumbai, Maharashtra, India. Reliance owns businesses across India engaged in energy, petrochemicals, textiles, natural resources, retail, and telecommunications [7].

9) Indian Oil Corporation Limited, commonly known as Indian Oil is an Indian state owned oil and gas company with registered office at Mumbai and primarily headquartered in New Delhi. It is the largest commercial oil company in the country, with a net profit of INR 19,106 crore for the financial year 2016-17 [7].

10) A $\$ 13$ billion. Conglomerate, JSW Group is one of India's largest business conglomerates. It is led by Sajjan Jindal and part of the US \$15 billion O. P. Jindal Group. Earlier, the name was Jindal South West. Later, the company adopted the name of JSW to promote it as a brand [7].

The data for the M \& A deals analysis has been sourced CMIE-Prowess and for the acquirer company has been sourced from Moneycontrol.com. Money control gives the data for ratios whereas CMIE-Prowess gives details about the deals, it does not give calculation of ratios. Hence for deal details CMIE-Prowess was used and for ratio Money control was used for data collection. An average of three years pre-merger and post-merger data has been compared. The data includes selected efficiency ratios. In order to statistically prove that the merger has had an impact on the efficiency of the acquirer company post-merger, the paired $t$ test has also been used. This tests will show whether the post-merger performance is statistically different from the pre-merger performance.

1) Select Financial Ratios

Total Asset Turnover, Fixed Asset Turnover, Inventory Turnover ratio, Debtors Turnover ratio, Creditors Turnover ratio, Working capital turnover ratio [10].

a) Total Asset Turnover-The asset turnover ratio is calculated by dividing net sales by average total assets. Net sales, found on the income statement, are used to calculate this ratio returns and refunds must be backed out of total sales to measure the truly measure the firm's assets' ability to generate sales [10].

b) Fixed Asset Turnover-It is a ratio of net sales to fixed assets. This ratio specifically measures a company's ability to generate net sales from fixed-asset investments, namely property, plant and equipment (PP \& E), net of depreciation [10].

c) Inventory Turnover-The inventory turnover ratio is an efficiency ratio that shows how effectively inventory is managed by comparing cost of goods sold with average inventory for a period [10].

d) Debtors Turnover-The receivables turnover ratio is an activity ratio measuring how efficiently a firm uses its assets. Receivables turnover ratio can be calculated by dividing the net value of credit sales during a given period by the 
average accounts receivable during the same period.

e) Creditors Turnover-Accounts payable turnover ratio (also known as creditors turnover ratio or creditors' velocity) is computed by dividing the net credit purchases by average accounts payable. It measures the number of times, on average, the accounts payable are paid during a period.

f) Working capital turnover ratio-he working capital turnover ratio is calculated by dividing net annual sales by the average amount of working capitalcurrent assets minus current liabilities during the same 12-month period.

2) Paired t-test

The paired sample t-test is used is used to assess whether the mean difference between two sets of data is zero or not. The means of two samples can be calculated which can be in the form of data pre and post an event and understand if there is any difference between the means of the data or not. Here T-test is conducted to understand the effect of mergers on the performance of the company before and after the merger.

Two Hypothesis - the null hypothesis and the alternative hypothesis is considered for testing. The null hypothesis will assess that the mean difference between pre and post data is zero and the alternative hypothesis will assume that the mean difference between the two is not equal to zero. The test is considered at $5 \%$ significance.

\section{Analysis and Findings}

In this study, two periods of data have been considered for analysis-pre-merger and post-merger Efficiency ratio of the Indian acquirer company in selected $M$ \& A deals in the periods-2007-2008 and 2012-13. To compare performance of the acquirer company pre and post merger, an average of three years selected efficiency ratios is calculated for each acquirer company. The year of the merger has not been considered in the calculation of the average.

Performance of select M \& A deals in the period 2007-08

For the period 2007-08, 11 cross-border M \& A deals are included and Table 1 shows the average of the three years ratios.

Based on Table 1, in terms of efficiency it appears that the average Total asset turnover ratio for three out of eleven companies has improved post-merger, Inventory turnover ratio has improved only in the case of Colgate-Palmolive, Drs Turnover ratio has improved post-merger for three out of eleven companies. In terms of Fixed asset turnover ratio shows an improvement only in two cases out of seven. It is only in the case of Colgate-Palmolive as an acquirer that improvement is seen in all the selected ratios.

To empirically prove that post-merger there is a significant difference in the performance of the acquirer company, the paired t test has been used.

Table 2 shows the results of the paired t test for the selected ratios in the period 2007-2008. The null hypothesis for the paired t test states that the mean difference in average selected ratios pre-merger and post-merger is 0 . Because the p-value in Table 2 for all the selected ratios are greater than the significance level 
Table 1. Selected ratios (average) of acquirer company-2007-08.

\begin{tabular}{|c|c|c|c|c|c|c|c|c|c|c|c|c|}
\hline & $\begin{array}{l}\text { T.A.T/O } \\
\text { PRE }\end{array}$ & $\begin{array}{l}\text { T.A T/O } \\
\text { Post }\end{array}$ & $\begin{array}{c}\text { F.A. } \\
\text { T/O/Pre }\end{array}$ & $\begin{array}{l}\text { F.A. T/O } \\
\text { Post }\end{array}$ & $\begin{array}{c}\text { INVENTORY } \\
\text { T/O Pre }\end{array}$ & $\begin{array}{l}\text { INVENTORY } \\
\text { T/O Post }\end{array}$ & $\begin{array}{l}\text { DRS } \\
\text { T/O Pre }\end{array}$ & $\begin{array}{c}\text { DRS } \\
\text { T/O Post }\end{array}$ & $\begin{array}{l}\text { CRS } \\
\text { T/O } \\
\text { Pre }\end{array}$ & $\begin{array}{l}\text { CRS } \\
\text { T/O } \\
\text { Post }\end{array}$ & $\begin{array}{l}\text { W.CAP } \\
\text { T/O Pre }\end{array}$ & $\begin{array}{l}\text { W.CAP } \\
\text { T/O Post }\end{array}$ \\
\hline $\begin{array}{l}\text { Dr.Reddy's } \\
\text { Laborarories }\end{array}$ & 0.08 & 0.08 & 0.07 & 0.07 & 0.06 & 0.06 & 0.05 & 0.06 & 0.01 & 0.00 & 0.05 & 0.05 \\
\hline Colgate Palmolive & 0.06 & 0.09 & 0.26 & 0.61 & 0.24 & 0.57 & 0.11 & 0.20 & 0.01 & 0.00 & 0.11 & 0.20 \\
\hline Tata Motors & 0.04 & 0.02 & 0.14 & 0.05 & 0.09 & 0.03 & 0.05 & 0.02 & 0.03 & 0.00 & 0.05 & 0.02 \\
\hline Suzlon & 0.11 & -0.04 & 0.10 & -0.09 & 0.17 & -0.06 & 0.09 & -0.03 & 0.08 & -0.02 & 0.09 & -0.03 \\
\hline ONGC & 0.14 & 0.15 & 0.13 & 0.10 & 0.09 & 0.08 & 0.06 & 0.06 & 0.01 & 0.00 & 0.06 & 0.06 \\
\hline Hindalco & 0.06 & 0.02 & 0.07 & 0.08 & 0.04 & 0.03 & 0.03 & 0.04 & 0.08 & 0.01 & 0.02 & 0.03 \\
\hline Tata Steel & 0.09 & 0.02 & 0.21 & 0.10 & 0.12 & 0.03 & 0.08 & 0.02 & 0.03 & 0.01 & 0.08 & 0.02 \\
\hline $\begin{array}{c}\text { HDFC -Centurion } \\
\text { BOP }\end{array}$ & 0.07 & 0.03 & 0.11 & 0.05 & 0.11 & 0.04 & 0.08 & 0.03 & 0.03 & 0.01 & 0.08 & 0.02 \\
\hline $\begin{array}{c}\text { Reliance } \\
\text { Industries-IPCL }\end{array}$ & 0.05 & 0.06 & 0.11 & 0.07 & 0.06 & 0.05 & 0.04 & 0.05 & 0.01 & 0.01 & 0.06 & 0.03 \\
\hline Indian oil Corp-IBP & 0.08 & 0.04 & 0.13 & 0.05 & 0.07 & 0.06 & 0.06 & 0.03 & 0.02 & 0.01 & 0.04 & 0.03 \\
\hline JSW-SISCOL & 0.09 & 0.03 & 0.08 & 0.09 & 0.09 & 0.03 & 0.09 & 0.05 & 0.02 & 0.13 & 0.04 & 0.03 \\
\hline
\end{tabular}

Table 2. Hypothesis testing-1 of acquirer companies for period 2007-08.

\begin{tabular}{cccccc}
\hline & \multicolumn{3}{c}{ Paired Sample Statistics } & \multicolumn{2}{c}{ Paired t test } \\
\cline { 2 - 6 } & $\mathrm{N}$ & Mean & Std. Deviation & $\mathrm{t}$ & Sig. (2-tailed) \\
\hline T.A.T/O PRE & 11 & 16.39 & 7.18 & 1.4 & 0.21 \\
T.A.T/O POST & 11 & 9.82 & 12.42 & & \\
F.A. T/O/Pre & 11 & 23.34 & 13.74 & 0.19 & 0.85 \\
F.A. T/O/Post & 11 & 20.88 & 41.76 & & \\
INVENTORY T/O Pre & 11 & 13.32 & 5.38 & 0.75 & 0.48 \\
INVENTORY T/O Post & 11 & 9.53 & 14.97 & & \\
DRS T/O Pre & 11 & 12.82 & 6.2 & 0.54 & 0.61 \\
DRS T/O Post & 11 & 10.03 & 14.78 & & \\
CRS T/O Pre & 11 & 3 & 6.58 & 0.89 & 0.41 \\
CRS T/O Post & 11 & 0.16 & 2.03 & & 0.9 \\
W.CAP T/O Pre & 11 & 27.61 & 14.13 & 0.13 & \\
W.CAP T/O Post & 11 & 25.86 & 44.58 & & \\
\hline
\end{tabular}

of 0.05 , the decision is to accept the null hypothesis and conclude that there is a no difference in the average selected financial pre-merger and post-merger.

Performance of select M \& A deals in the period 2012-13

For the period 2012-13, 12 cross-border M \& A deals are included and Table 3 shows the average of the three years' ratios. 
Asian Paints-EssEss Bathroom Products

TCS-CMC

RIL-Network 18 Media and Investments

Tata Power-PT Arutmin Indonesia

Merck-Sigma Deal

Sterling Resorts-Asarco

Wipro-Opus CMC

Cipla-CiplaMedpro

Amtek Auto-Kuepper Group

Jindal Poly Films-ExxonMobil Chemical Business

Sun Pharmaceutical Industries-Ranbaxy

Godrej Industries-Swadeshi Detergents

Table 3. Selected efficiency ratios (average) of acquirer company-2012-13.

\begin{tabular}{|c|c|c|c|c|c|c|c|c|c|c|c|c|}
\hline & $\begin{array}{l}\text { T.A.T/O } \\
\text { PRE }\end{array}$ & $\begin{array}{l}\text { T.A T/O } \\
\text { Post }\end{array}$ & $\begin{array}{l}\text { F.A. } \\
\text { T/O/Pre }\end{array}$ & $\begin{array}{l}\text { F.A. T/O } \\
\text { Post }\end{array}$ & $\begin{array}{c}\text { INVENTORY } \\
\text { T/O Pre }\end{array}$ & $\begin{array}{c}\text { INVENTORY } \\
\text { T/O Post }\end{array}$ & $\begin{array}{l}\text { DRS } \\
\text { T/O Pre }\end{array}$ & $\begin{array}{c}\text { DRS T/O } \\
\text { Post }\end{array}$ & $\begin{array}{c}\text { CRS T/O } \\
\text { Pre }\end{array}$ & $\begin{array}{c}\text { CRS T/O } \\
\text { Post }\end{array}$ & $\begin{array}{l}\text { W.CAP } \\
\text { T/O Pre }\end{array}$ & $\begin{array}{l}\text { W.CAP } \\
\text { T/O Post }\end{array}$ \\
\hline $\begin{array}{l}\text { ASIAN } \\
\text { PAINTS }\end{array}$ & 0.06 & 0.06 & 0.21 & 0.16 & 0.19 & 0.15 & 0.11 & 0.09 & 0.02 & 0.01 & 0.82 & 0.78 \\
\hline TCS & 0.13 & 0.14 & 0.20 & 0.20 & 0.20 & 0.19 & 0.14 & 0.15 & 0.02 & 0.02 & 0.55 & 0.57 \\
\hline RIL & 0.04 & 0.04 & 0.06 & 0.06 & 0.04 & 0.04 & 0.03 & 0.03 & 0.01 & 0.01 & 0.46 & 0.40 \\
\hline $\begin{array}{c}\text { TATA } \\
\text { POWER }\end{array}$ & 0.07 & 0.05 & 0.05 & 0.03 & 0.03 & 0.02 & 0.02 & 0.01 & 0.01 & 0.01 & 0.17 & 0.13 \\
\hline MERCK & 0.06 & 0.03 & 0.08 & 0.05 & 0.08 & 0.04 & 0.06 & 0.04 & 0.00 & 0.02 & 0.54 & 0.61 \\
\hline $\begin{array}{l}\text { STERLING } \\
\text { RESORTS }\end{array}$ & -0.13 & -0.26 & 0.16 & 0.40 & -0.02 & -0.06 & -0.01 & -0.05 & -0.04 & 0.00 & 0.05 & 0.10 \\
\hline WIPRO & 0.08 & 0.06 & 0.08 & 0.06 & 0.08 & 0.06 & 0.06 & 0.05 & 0.00 & 0.00 & 0.36 & 0.36 \\
\hline CIPLA & 0.08 & 0.06 & 0.08 & 0.06 & 0.08 & 0.06 & 0.06 & 0.05 & 0.00 & 0.00 & 0.36 & 0.36 \\
\hline $\begin{array}{c}\text { AMTEK } \\
\text { AUTO }\end{array}$ & 0.05 & -0.07 & 0.02 & -0.02 & 0.01 & -0.01 & 0.01 & 0.00 & 0.00 & 0.01 & 0.11 & 0.10 \\
\hline $\begin{array}{c}\text { JINDAL } \\
\text { POLY FILMS }\end{array}$ & 0.07 & 0.03 & 0.11 & 0.05 & 0.08 & 0.04 & 0.06 & 0.03 & 0.00 & 0.00 & 0.46 & 0.52 \\
\hline $\begin{array}{c}\text { Sun } \\
\text { Pharmaceutical } \\
\text { Industries }\end{array}$ & 0.20 & -0.03 & 0.10 & -0.06 & 0.10 & -0.05 & 0.09 & -0.03 & 0.00 & 0.00 & 0.09 & -0.03 \\
\hline $\begin{array}{c}\text { Godrej } \\
\text { Industries }\end{array}$ & 0.02 & 0.02 & 0.06 & 0.04 & 0.05 & 0.03 & 0.03 & 0.02 & 0.01 & 0.01 & 0.03 & 0.02 \\
\hline
\end{tabular}

1) Asian Paints Limited is an Indian multinational paint company headquartered in Mumbai, Maharashtra. The Company is engaged in the business of manufacturing, selling and distribution of paints, coatings, products related to home decor, bath fittings and providing of related services [10].

2) Tata Consultancy Services Limited is an Indian multinational information technology service, consulting company headquartered in Mumbai, Maharash- 
tra. It is part of the Tata Group and operates in 46 countries. TCS is one of the largest Indian companies by market capitalization [10].

3) Reliance Industries Limited is an Indian conglomerate holding company headquartered in Mumbai, Maharashtra, India. Reliance owns businesses across India engaged in energy, petrochemicals, textiles, natural resources, retail, and telecommunications [10].

4) Tata Power Limited is an Indian electric utility company based in Mumbai, Maharashtra, India and is part of the Tata Group. The core business of the company is to generate, transmit and distribute electricity [10].

5) Merck was incorporated in India as E. Merck India Private Limited in 1967. In 2017 it completed 50 years in India, starting out as a pharmaceutical company and growing to become a science and technology business spanning all the sectors of Healthcare, Life Science and Performance Materials [10].

6) Sterling Holiday Resorts Limited a holiday lifestyle company was incorporated in the year 1986. In 2015, Sterling Holiday Resorts India Limited became a $100 \%$ independently managed subsidiary of Thomas [10].

7) Wipro Limited is an Indian multinational corporation that provides information technology, consulting and business process services. It is headquartered in Bengaluru, India. In 2013, Wipro demerged its non-IT businesses into separate companies [10].

8) Cipla Limited is an Indian multinational pharmaceutical and biotechnology company, headquartered in Mumbai, India. Cipla primarily develops medicines to treat respiratory, cardiovascular disease, arthritis, diabetes, weight control and depression; other medical conditions [10].

9) The Amtek Group, headquartered in India, is one of the largest integrated component manufacturers in India with a strong global presence. It has also become one of the worlds largest global forging and integrated machining companies [10].

10) Jindal Poly Films Limited is a part of the $\$ 2$ billion B.C. Jindal group, which has been offering a wide range of products and solutions for more than 6 decades. The group is involved in diverse businesses including Polyester \& Polypropylene films, Steel pipes, Thermal Power Generation and Photographic products [10].

11) Sun Pharmaceutical Industries Limited is an Indian multinational pharmaceutical company headquartered in Mumbai, Maharashtra that manufactures and sells pharmaceutical formulations and active pharmaceutical ingredients primarily in India and the United States [10].

12) The Godrej Group is an Indian conglomerate headquartered in Mumbai, Maharashtra, India, managed and largely owned by the Godrej family [10].

Based on Table 3, in terms of Debtors Turn over efficiency, it appears that the for three out of twelve companies has improved post-merger, return on assets has improved post-merger only in the case of TCS. In terms of productivity, the asset turnover ratio shows that the ratio has remained the same or declined post-merger for all eight out of the twelve deals. 
Table 4. Hypothesis testing-1 of acquirer companies for period 2012-13.

\begin{tabular}{|c|c|c|c|c|c|}
\hline & \multicolumn{3}{|c|}{ Paired Sample Statistics } & \multicolumn{2}{|c|}{ Paired $t$ test } \\
\hline & $\mathrm{N}$ & Mean & Std. Deviation & $\mathrm{t}$ & \\
\hline T.A.T/O PRE & 12 & 12.28 & 15.03 & 2.44 & 0.03 \\
\hline T.A.T/O POST & 12 & 2.31 & 19.96 & & \\
\hline F.A. T/O/Pre & 12 & 15.3 & 12.98 & 3.05 & 0.01 \\
\hline F.A. T/O/Post & 12 & 8.63 & 14.22 & & \\
\hline INVENTORY T/O Pre & 12 & 11.19 & 8.67 & 2.63 & 0.02 \\
\hline INVENTORY T/O Post & 12 & 6.27 & 10.64 & & \\
\hline DRS T/O Pre & 12 & 66.78 & 49.34 & 0.55 & 0.59 \\
\hline DRS T/O Post & 12 & 65.06 & 52.16 & & \\
\hline CRS T/O Pre & 12 & -0.49 & 2.58 & -1.2 & 0.26 \\
\hline CRS T/O Post & 12 & 0.14 & 0.52 & & \\
\hline W.CAP T/O Pre & 12 & 20.22 & 11.93 & 0.6 & 0.56 \\
\hline W.CAP T/O Post & 12 & 17.03 & 24.06 & & \\
\hline
\end{tabular}

See [11].

Table 4 shows the results of the paired t test for the selected ratios in the period 2012-13. The null hypothesis for the paired t tests states that the mean difference in average selected ratios pre-merger and post-merger is 0 . The p-value in Table 4 above for the 3 selected ratio is less than the level of significance of 0.05 , the decision is to reject the null hypothesis and conclude that there is the difference in the average of selected ratios (pre-merger and post-merger). Based on the above results, it appears the performance of the acquired companies in both the periods 2007-08 and in 2012-13 did not show appreciable value accretion to the company in question. However, in the period 2007-08, on the basis of efficiency ratios, it appears that the proportion of companies showing positive change post-merger is greater than companies in 2012-13. This could be attributed to the weak global and domestic scenario in 2012-13. In 2008 due to financial crisis also there could be a reason for the efficiency going down. Despite the variation in drivers for $M \& A$ in the two period under study, the performance of the acquirer companies improved marginally or actually deteriorated.

The findings can be attributed to many factors including Indian companies paying less than required attention to integration issues early in a deal. International companies, on the other hand, before inking the deal, demand for a detailed synergy assessment and integration plan. Other factors could be that after the deal, the acquired asset may not hold as much attention and be allowed to run down in value and cultural disparity and post-integration hurdles. Indian companies still need to improve on skills required to monitor the success of deal while the target may be looking for cost savings, synergies for the new arrangement. The study found that Indian companies are more adept when merging 
with Indian target companies.

Indian companies look for cross-border acquisition for access to natural resources, technology or skills, create scale and new international markets for their products or services and diversification into new products or markets. It is imperative to have a post-merger plan in place, except maybe when raw material price arbitrage is the key focus and it appears that few Indian acquiring companies have the plan well in sight.

\section{Conclusion}

The period under study reveals that the whole M \& A deals appears to have added less than expected value to the acquirer company. This could be on account of many factors including macroeconomics environment (timing of the deal) and the drivers for merger from the perspective of the acquirer company. It appears that there are some overarching factors leading to constrain the performance of the Indian acquirer companies, global financial crisis. The period understudy was restricted for pre-1 year and post-1 year, long term study can be done to study the impact over a period of time.

\section{Acknowledgements}

Thanks Dr. G. Ramesh (SFIMAR) for critically reviewing paper for its quality improvement.

\section{Conflicts of Interest}

The author declares no conflicts of interest regarding the publication of this paper.

\section{References}

[1] Amishsoni, M. (2016) A Study on Mergers and Acquisition and Its Impact on Shareholders Wealth. IOSR Journal of Business and Management (IOSR-JBM), 18, 79-86.

[2] Bedi, H.S. (2010) Merger \& Acquisition in India: An Analytical Study. National Conference on Business Innovation, Apeejay Institute of Management, Punjab.

[3] Pandya, V.U. (2017) Mergers and Acquisitions Trends-The Indian Experience.

[4] Kar, R.N. and Soni, A. Mergers and Acquisitions in India: A Strategic Impact Analysis for the Corporate Enterprises in the Post Liberalization Period 2017.

[5] Agnihotri, A. (2013) Determinants of Acquisitions: An Indian Perspective. Management Research Review, 36, 882-898. https://doi.org/10.1108/MRR-04-2012-0077

[6] Erel, Liao and Weisbach (2012) Mergers and Acquisition-Determinants of Cross border Approach.

[7] Kumar, S. and Bansal, L.K. (2009) The Impact of Mergers and Acquisitions on Corporate Performance in India. https://doi.org/10.1108/00251740810920029

[8] Motis, J. (2007) Mergers and Acquisitions Motives. The ICFAI Journal of Mergers and Acquisition, 4, 52-66.

[9] Arora, M. and Kumar, A. (2012) A Study on Merger's and Acquisition and Its Im- 
pact on Management and Employees. Research Journal of Economics and Business Studies.

[10] https://www.moneycontrol.com/stocksmarketsindia/

[11] Suri, D. and Pandey, D. (2017) Impact on Mergers and Acquisition on Indian Acquirer Paper. IBS International Conference. 